\title{
Employability Skills Indicator as Perceived by Manufacturing Employers
}

\author{
Mohamad Sattar Rasul ${ }^{1}$, Rose Amnah Abd. Rauf ${ }^{2}$ \& Azlin Norhaini Mansor ${ }^{1}$ \\ ${ }^{1}$ Faculty of Education, Universiti Kebangsaan Malaysia, Bangi, Malaysia \\ ${ }^{2}$ Faculty of Education, University Malaya, Kuala Lumpur, Malaysia \\ Correspondence: Mohamad Sattar Rasul, Faculty of Education, Universiti Kebangsaan Malaysia, Bangi 43600, \\ Selangor, Malaysia. E-mail: drsattar@ukm.my
}

\author{
Received: February 12, 2013 Accepted: March 29, 2013 Online Published: April 25, 2013 \\ doi:10.5539/ass.v9n8p42 URL: http://dx.doi.org/10.5539/ass.v9n8p42
}

\begin{abstract}
Research on employability skills were conducted nationally and internationally, found that many technical graduates lacked employability skills. This article reports on the study of employability skills that technical students should acquire to be employed and sustained in manufacturing industries. The study investigates the importance of employability skills as perceived by 107 employers from manufacturing industries. The findings of the study revealed employers place great importance on interpersonal skills, thinking skills and personal qualities that students need to emphasize to be employed in manufacturing industries. Indicators such as work safety, integrity, customer service, creative/innovative thinking and problem solving, and exercise leadership showed the highest mean score. Overall employers from manufacturing industries placed employability skills as must be owned by all graduates to enable them to compete in the global market.
\end{abstract}

Keywords: employability skills, manufacturing industry, employers, employees, technical students

\section{Introduction}

\subsection{Problem Background}

Employability skill is often defined as a preparation for graduates to successfully get jobs and to develop in their careers (Fugate et al., 2004), and enable individuals to prove their value to an organization as the key to job survival (Askov \& Gordon, 1999). The background theory often related to employability skills development is the human capital theory, which states "employability" is not only about shaping talent, techniques, and experience for an individual to get a job, but more towards the ability to do the work (Schultz, 1963). Employability skills are also known as transferable core skill groups that represent essential functional and enabling knowledge, skills, and attitudes required by the 21 st century workplace (SCANS, 1991a) and industrial employers agree that to be outstanding in their field, employability is an important skill to be acquired by their employees. Employers are looking for graduates who have skills in three major areas: 1) strong academic and thinking skills; 2) strong technical skills in the field in which they work; and 3) employability skills such as the ability to work in teams and communicate effectively.

Industry analysts reported that for success in the workplace, employees need to possess entry-level employability skills that are often viewed as a company's most important raw material (Wesselink, Jong, \& Biemans, 2009). Thus identifying indicators for employability skills from the employer's perspective is crucial to develop students' employability skills. The institutions of education must produce graduates who not only have technical skills but also employability skills.

\subsection{Issues on Employability Skills}

Studies on technical and vocational education on employability, showed that technical graduates had mastered their technical skills but employers however felt dissatisfied with their employees motivational skills, communication skills, interpersonal skills, critical thinking, problem solving and entrepreneurship skills (Ramlee, 2002 \& Kathleen, 2005).

Ahmad (2005) in his study on technical graduates found that 80.000 technical graduates who are still unemployed was because they largely depended on academic qualifications to get a job but lack nontechnical 
skills (employability skills). Thus, making employers seek competent workers from abroad. Meanwhile based on the research done by Fitrisehara et al. (2009), students employability skill is at moderate level. Aspect that has the lowest score is information skill while the aspect that has the highest score is personal quality. There are significant differences between employability skill and the students' field of studies.

A study on undergraduates' core competencies ability to meet with the requirements set by the employers in private university in Malaysia was done. The findings showed that undergraduates were all highly competent in possessing personal qualities and skills. However, such skills as critical analysis, planning, problem solving, oral communication, decision making, and negotiating report a slightly higher level of mismatch between employers' and undergraduates' perception on their importance and development in the (MOHE, 2009).

\subsection{Employability Skills Construct and Models}

The Secretary's Commission on Achieving Necessary Skills (SCANS, 1991b) was given the task to investigate whether high school students were capable of meeting the demands of the workplace. SCANS identified five competencies important for students to enter the workplace which are; 1) identifying, organizing, planning, and allocating resources, 2) working with others, 3) acquiring and using information, 4) understanding complex interrelationships, and 5) working with a variety of technologies. SCANS also categories foundational skills into three groups; basic skills, thinking skills and interpersonal qualities. It is predicted that jobs in the future will need people that can apply knowledge into their work.

Ministry of Higher Education of Malaysia (MOHE) aims at developing the students' potential by providing them with the knowledge and skills they can use through workplace experience. In this program, apart from technical skills, generic skills are also expected to be applied in the workplace so that the students become skilled workers. The generic skills to be mastered are: communication skills, technology, planning and organizing activities, working with others, problem solving, analytical, using mathematical ideas and techniques, and understanding culture (MOHE, 2006).

Malaysian Qualification Agency (MQA) outlines eight domains to be mastered by students. These are non-technical skills: knowledge in the areas studied, practical skills, social skills and responsibility, the value, attitude and professionalism, communication skills, leadership and teamwork, scientific problem-solving skills, entrepreneurial and management skills, lifelong learning skills and information management (MQA, 2006). MQA developed a Malaysian Qualifications Framework (MQF) as an accreditation instrument for all higher education providers. Meanwhile MOHE (2006) soft skills model includes generic skills across multiple domains of learning and skills group of personal aspects. University graduates should possess these skills to meet labour market needs and challenges of everyday life. Mastery of soft skills among the graduates will be able to compete in the job market. In principle, all public universities in Malaysia should adopt all seven elements of the soft skills. Elements of soft skills by MOHE include: communication skills, critical thinking skills, teamwork skills, continuous Learning, Entrepreneurship, ethical and moral professional skills, and leadership skills.

\section{Objectives of Study}

The objective of this study is to identify employability skills indicators for technical students required by the employers. These indicators are useful for the development of student's correct and employability skills.

\section{Methodology}

This study used a descriptive research design with quantitative approached. Quantitative data for this study were obtained through questionnaires. The items in the questionnaires has been adapted from SCANS (1991b) contained of seven constructs which are: 1) basic skills, 2) thinking skills, 3) resource management skills, 4) informational skills, 5) interpersonal skills, 6) system and technology skill, 7) personal quality skills.

Data was analyzed using the descriptive and inferential statistics. Descriptive analysis involves frequencies, percentages, mean and standard deviation whereas inferential analysis involves t-Test and ANOVA. Frequencies and percentages are used to explain the demographic items of respondents whereas mean and standard deviation are used to analyze level of employability skill of respondents. T-test is conducted to identify the differences between employability skills with the demographic variables. ANOVA is used to examine whether there are any differences among the employability skills based on

The employers chosen were grouped into five types of manufacturing industry, which were: electrical and electronic product (E \& E), metal based products (MB), machinery and equipment (ME), transport equipment (TE), and other kinds of product industry (OT). The type of company was based on the MIDA's categorization of manufacturing industry in Malaysia (MIDA, 2008). 
The instrument for survey was pilot test and the result in Table 1 shows the reliability (Cronbach Alpha) of seven items in the employability skills domain. The highest score are basic skills $(0.93)$, followed by the system and technology skills $(0.92)$, informational skills $(0.91)$, thinking skills $(0.89)$, resources skills $(0.87)$, interpersonal skills (0.87), and personal quality (0.85). All the variables used in this study showed Cronbach Alpha values more than 0.6 indicating that the chosen item are consistent and reliable.

Table 1. Cronbach Alpha values

\begin{tabular}{lcc}
\hline Skills Aspects & Item & CronbachAlpha \\
\hline Basic & 5 & 0.93 \\
Thinking & 6 & 0.89 \\
Resource & 5 & 0.87 \\
Informational & 4 & 0.91 \\
Interpersonal & 6 & 0.87 \\
System and Technology & 5 & 0.92 \\
Personal Quality & 9 & 0.85 \\
\hline
\end{tabular}

\section{Results and Discussions}

The results showed that employers in all five categories of manufacturing industry are in agreement on the importance of all seven of the employability skills.

The finding of the research shows that the aspect of interpersonal skills such as leadership ability, teaching others and working with cultural diversity has the highest mean score. For the interpersonal skills, working as a team is seen as a very important skill. Employers stress that every position in any size of industry require some kind of teamwork hence it is essential for employees to understand cultural, gender and age factors in ensuring effective teamwork. The skill to be able to transfer between individual work and team work is an advantage (McLeish, 2002) and they found that employers felt that team work and dedication were extremely important (Alston et al., 2009). The ability to lead is very important in any occupations. According to Zirkle (1998) and Gabriel (2000) most vocational instructors stated that leadership skill is very important to develop because it is needed as a part of preparation to enter the working world.

The next most important aspect of employability skills is the thinking skill, 'problem solving, creative and innovative thinking, knowing how to learn and reasoning. Reasoning is significant to make quick decisions logically or to interpret something and making conclusion out of them. The conclusion done should be based on thinking as well as other related considerations. Logical thinking is similar to critical thinking where the knowledge gained from reading materials for instance can be combined with useful information in daily activities (Emery, 1999). The basic of critical thinking is knowledge and is important to enable a person to discuss certain topics and to make overall conclusion (Brooks \& Everett, 2009).

The findings of the research also show that the basic skills, the 'mathematics' item have a high mean score (Mean=4.05). Mathematics is an important element to carry out duty especially production works and works which involved technological tools. According to De Leon and Borchers (1998), employers in Texas valued mathematic skill as the second most important skill where the skill was not provided by employers yet it is strictly required in occupations. Brockmann, Clarke, Mehaut \& Winch, (2008) stated that employers pointed out that they needed workers with basic mathematic skills and stressed that employer gives priority to mathematical skill and basic calculations when working such as the usage of mathematics in computer and calculator.

Aspect of resource skills (time, financial, materials and resources, human resource and risk management) viewed by employers has high mean score from 4.21 to 4.46 . The pressure on industry to grow and find new markets is leading to the identification of this area of skill as critical to employability. The employers suggested that employees must no longer rely on managers to take initiatives in developing the business or identifying new approaches (Godfrey, 1997).

For the aspect of informational skills, the sub-skills 'organizes and maintains information' showed an moderate mean score $($ mean $=3.73)$. Employees need to be able to manage time, manage self and work alone, be resourceful, make decision because they may be required to manage projects from concept development to 
completion of the project [9].

Apart from that, the item that has a high mean score in the aspects of system and technology are select system (mean=4.47) and understand system $(m e a n=4.34)$. The application of technology to perform tasks among employees who serve in the production field is very significant as contemporary industries used various latest technologies from foreign countries to simplified works. Bunn and Stewart (1998) reported that the skills to use technologies are crucial to develop basic skills, and the basic skills developed could assist vocational graduates to prepare skills required in the industry.

As for the aspect of personal quality, 'adaptability and flexibility" has the moderate mean score (Mean=3.48) but employers feel that personal values such as self-esteem, sociability, self-management, responsibility, integrity, work safety, and conscientiousness are important no matter how good their academic qualification they have. These values are seen to contribute to harmony and productivity within workplace and to developing good relations with customers. Bennet (2006) clarified that employer need workers who are able to face any challenge in workplace besides able to motivate themselves to get through those challenges.

\section{Conclusion}

Interpersonal skills have the highest mean score. Given the high value of these skills perhaps employers would like to see these skills incorporated more into the curricula to give more impact in preparing for work. Indicators such as problem solving skill, employers felt that these skills are very important and give a very high impact to the industry. High ability in problem solving skills will contribute to high quality of work, service and product as well as individual self-regard and well-being.

In relation to communication skills, employers felt that understanding instructions, listening, and verbalizing are important in the work place. Employers felt, given the need to be able to communicate effectively in work, institutions should place great emphasis on these in their curricula. Relating to resource skills, employers indicated that the financial management is important. Technical students are encouraged to get involved in in financial management and these skills should be included in program in order to expose students to the business and industrial world.

Employers indicated that all aspects of system and technology are important. The application of technology to perform tasks among employees who serve in the production field is very significant as industries use various latest technologies to simplify work. It is crucial to develop these skills in technical students'. As for the aspect of personal quality, the item adaptability and flexibility is moderately important to employers but it is an advantage for student to have because with these skills, students are able to face any challenge in the workplace besides being able to motivate themselves to get through those challenges and working with various races, cultures and languages.

The results of these findings can be useful as a guide for technical instructors or lecturer to plan which employability skills should be emphasize, and considered important to be acquired by students before working in the industry. The findings also can be useful to graduates or job seekers in the manufacturing industry to be prepared with the expectations of employers.

In this study, the result showed that employers rated most of the employability skills at a high level. Therefore it is suggested that the authorities of education institution should enhance the important employability skills either through the professional development of lecturers, curriculum and co curriculum. Instructors should inculcate and evaluate employability skills so that they could assist students to understand ways of applying these skills and produce students achievement feedback. Apart from that, programs should carry out real working environment for students to be able to understand employability skills better. These will serve the purpose to make students realize the importance of employability skills.

\section{References}

Alston, A. J., Cromartie, D., Wakefield, D., \& English, C. W. (2009). The importance of employability skills as perceived by the employers of united states' land-Grant College and university graduates. Journal of Southern Agricultural Education Research, 59, 56-69.

Askov, E. N., \& Gordon, E. E. (1999). The brave new world of workforce education. New Directions for Adult and Continuing Education, 83, 59-68. http://dx.doi.org/10.1002/ace.8305

Bennett, T. M. (2006). Defining the Importance of Employability Skills in Technical Education. Dissertation.Auburn University.

Brockmann, M., Clarke, L., Méhaut, P., \& Winch, C. (2008). Competence-Based Vocational Education and 
Training (VET): the Cases of England and France in a European Perspective. Vocations and Learning, 1(3), 227-244. http://dx.doi.org/10.1007/s12186-008-9013-2

Brooks, R., \& Everett, G. (2009). Post-graduation reflections on the value of a degree. British Educational Research Journal, 35(3), 333-349. http://dx.doi.org/10.1080/01411920802044370

Bunn, P. C., \&. Stewart, L. (1998). Perceptions of Technical Committee Members Regarding the Adoption of Skill Standards in Vocational Education Programs. Journal of Vocational and Technical Education, 14, $1-14$.

De Leon, J. E., \& Borchers, R. E. (1998). High School Graduate Employment Trends and the Skills Graduates Need to Enter Texas Manufacturing Industries. Journal of Vocational and Technical Education, 15, 1-19.

Emery, J. H. (1999). The Employability Skills Discourse: A Conceptual Analysis of the Career and Personal Planning Curriculum. Conceptual Analyses of CAPP.

Fitrisehara, K., Ramlah, H., \& Rahim, A. B. (2009). Employability Skills among the Students of Technical and Vocational Training Centers in Malaysia. European Journal of Social Sciences, 9(1), 147-160.

Fugate, M., Kinicki, A. J., \& Ashforth, B. E. (2004). Employability: A psychosocial construct, its dimension, and applications. Journal of vocational behavior, 65(2), 14-38. http://dx.doi.org/10.1016/j.jvb.2003.10.005

Gabriel, G. E. (2000). Employee Characteristics and Skills Valued by Northern Virginia Employers. Office of Institutional Research, Northern Virginia Community College.

Godfrey, M. (1997). Planning for Vocational Education, Training and Employment: A Minimalist Approach. International Journal of Manpower, 18, 206-227. http://dx.doi.org/10.1108/01437729710169346

Kathleen, C. (2005). Developing Employability Skills. Regional Educational Laboratory. School Improvement Research Series (SIRS)

McLeish, A. (2002). Employability Skills for Australian Small and Medium Sized Enterprises: Commonwealth of Australia.

MIDA (Malaysian Industrial Development Authority). (2008). Malaysia Performance of the Manufacturing and Services Sectors. Kuala Lumpur, Malaysia: Malaysian Industrial Development Authority.

MOHE (Ministry of Higher Education of Malaysia). (2009). Seminar on Employability: An Overview of Graduate Employability of Recent Graduates: Some Facts and Figures. Putrajaya, Malaysia.

MOHE (Ministry of Higher Education). (2006). Modul Pembangunan KemahiranInsaniah (Soft Skills) untukInstitusiPengajianTinggi Malaysia. Universiti Putra Malaysia. Selangor.

MQA (Malaysian Qualification Agency). (2006). Titik rujukan dan persefahaman bersama tentang kelayakan pengajian tinggi di Malaysia. Kuala Lumpur: Agensi Kelayakan Malaysia.

Ramlee, M. (2002). The role of vocational and technical education in the industrialization of Malaysia as perceived by educators and employers. Doctoral Dissertation.Purdue University.

SCANS. (1991a). Skills and Task for Jobs. A SCANS Report for America 2000. Washington, D.C. U.S. Department of Labour.

SCANS. (1991b). What Work Requires of Schools. A Secretary's Commission on Achieving Necessary Skills (SCANS). Report for America 2000. U.S. Department of Labor.

Schultz, T. W. (1963). The Economics Value of Education (3rd ed.). New York and London. Columbia. University Press.

Wesselink, R., Jong, C., \& Biemans, H. J. A. (2009). Aspects of Competence-Based Education as Footholds to Improve the Connectivity Between Learning in School and in the Workplace. Vocations and Learning, 3(1), 19-38. http://dx.doi.org/10.1007/s12186-009-9027-4

Zaini, A. (2005). Students and Employers as Customers of Multimedia College. Proceedings of National Seminar "The development of Technology And Technical-Vocational Education And Training In An Era of Globalization: Trend and Issues". Kuala Lumpur.

Zirkle, C. (1998). Perceptions of Vocational Educators and Human Resource/Training and Development Professionals Regarding Skill Dimensions of School-to-Work Transition Programs. Journal of Vocational and Technical Education, 15, 1-20. 